\title{
PENENTUAN PENERIMAAN BANTUAN SISWA MISKIN MENGGUNAKAN ANALITYCAL HIERARCHY PROCESS
}

\author{
Bunga Lestari ${ }^{1)}$, Nada Sri Rejeki ${ }^{2}$, Dudih Gustian ${ }^{3)}$, Muhamad Muslih ${ }^{4}$ \\ ${ }^{1)}$ Program Studi Sistem Informasi, Universitas Nusa Putra Sukabumi \\ Jl. Raya Cibolang No. 21 Sukabumi, Jawa Barat, 43152 Indonesia, Tlp.0266210594 \\ ${ }^{1)}$ lestaribunga03@gmail.com, ${ }^{2}$ nadasrirejeki9@gmail.com, ${ }^{3)}$ dudih@nusapaputra.ac.id, \\ 4)muhamadmuslih@nusaputra.ac.id
}

\begin{abstract}
ABSTRAK
Bantuan Siswa Miskin (BSM) adalah program nasional yang bertujuan untuk membantu meringankan siswa miskin untuk bersekolah dengan bantuan akses pelayanan pendidikan yang layak ,mencegah putus sekolah,menarik siswa miskin untuk kembali bersekolah. Tidak semua siswa yang berasal dari keluarga miskin dapat menerima Program Bantuan Siswa Miskin (BSM). Belum adanya Sistem Informasi dalam mendukung pengambilan keputusan dan pihak SMK Bina Mandiri 2 kesulitan dalam menentukan penerima BSM. Berdasarkan hal tersebut, penulis merancang sistem pendukung keputusan Penerima BSM menggunakan Analitycal Hierarchy Process di SMK Bina Mandiri 2. Metode Analitycal Hierarchy Process adalah suatu model pengambilan keputusan yang komprehensif dan terstruktur. Sistem ini dibangun dengan bahasa pemrograman Visual Basic 6.0 dan SQLyog sebagai database. Hasil penelitian menunjukkan bahwa sistem yang dibangun mampu memberikan hasil perhitungan secara otomatis sesuai dengan hasil perhitungan yang dilakukan secara manual. Diharapkan dengan sistem yang dirancang dapat membantu pengambil keputusan yang bersifat objektif dan pada proses penentuan penerima BSM yang lebih efisien
\end{abstract}

Kata Kunci : Bantuan Siswa Miskin, SMK Bina Mandiri 2, Analitycal Hierarchy Process

\section{ABSTRACT}

Assistance for Poor Students (BSM) is a national program that aims to help alleviate poor students to go to school with the assistance of access to proper education services, prevent dropouts, and attract poor students to return to school. Not all students who come from poor families can receive the Poor Student Assistance Program (BSM). There is no information system to support decision making and SMK Bina Mandiri 2 has difficulties in determining BSM recipients. Based on this, the authors designed a decision support system for BSM recipients using the Analitycal Hierarchy Process at SMK Bina Mandiri 2. The Analytical Hierarchy Process method is a comprehensive and structured decision-making model. This system is built with Visual Basic 6.0 programming language and SQLyog as database. The results showed that the system built was able to provide automatic calculation results in accordance with the results of calculations carried out manually. It is hoped that the designed system can assist objective decision makers and a more efficient process of determining BSM recipients.

Keywords: Assistance for Poor Students, SMK Bina Mandiri 2, Analitycal Hierarchy Process 


\section{PENDAHULUAN}

\subsection{Latar Belakang}

Bantuan Siswa Miskin (BSM) adalah program nasional yang bertujuan untuk membantu meringankan siswa miskin untuk bersekolah dengan bantuan akses pelayanan pendidikan yang layak ,mencegah putus sekolah,menarik siswa miskin untuk kembali bersekolah,membantu meringankan biaya pendidikan sekolah dan memenuhi kebutuhan dalam kegiatan pembelajaran. Melalui program Bantuan Siswa Miskin (BSM) ini diharapkan anak usia sekolah dari golongan keluarga miskin dapat terus bersekolah.

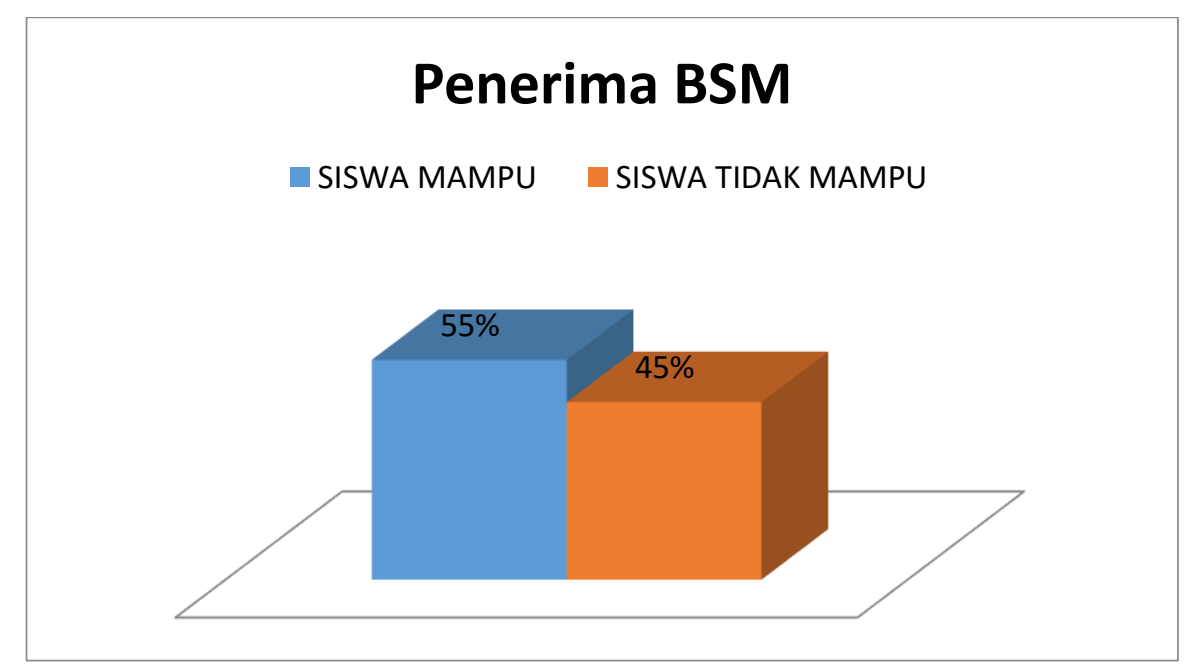

Gambar 1. Grafik Penerima BSM di SMK Bina Mandiri

Dari grafik diatas dapat dilihat presentase siswa mampu yang mendapatkan BSM lebih besar dibanding siswa tidak mampu, Dalam pelaksanaan program Bantuan Siswa Miskin (BSM),Pihak panitia seleksi penerimaan BSM di sekolah SMK BINA MANDIRI 2 sering menghadapi masalah dalam menentukan siswa-siswi yang berhak mendapatkan Bantuan Siswa Miskin (BSM). Misalnya tidak semua siswa yang berasal dari keluarga miskin dapat menerima Program Bantuan Siswa Miskin (BSM). Mengingat siswa-siswi SMK BINA MANDIRI 2 berjumlah 332 terdiri dari laki-laki 228 dan perempuan 104 dari kelas 10 sampai dengan kelas 12. Dengan jumlah tersebut kuota penerimaan BSM hanya 94 siswa dengan rincian dana BSM sebesar Rp 500.000 untuk kelas 10 dan kelas 11 dan Rp 1.000.000 untuk kelas 12. Permasalahan dalam menentukan calon penerima BSM disebabkan oleh kesamaan data dari berbagai siswa dan tidak adanya pendukung untuk mengelompokan data sesuai kebutuhan.Kesamaan data tersebut menjadi masalah dalam menentukan siswa yang layak menerima BSM sehingga program dapat tepat sasaran. Tentunya dibutuhkan Sistem Pendukung Keputusan (SPK) yang dapat membantu pihak sekolah dalam menentukan siswa mana yang lebih berhak mendapatkan BSM.

SPK adalah suatu sistem yang mampu menyediakan fungsi pengolahan data berdasarkan suatu model tertentu, sehingga user dari sistem tersebut dapat memilih alternatife keputusan terbaik. Metode yang digunakan dalam SPK adalah Metode Analytical Hierarchy Process (AHP). Kelebihan AHP adalah AHP mampu memecahkan permasalahan yang kompleks melalui pendekatan sistem dan pengintegrasian secara dedukatif [1].

Metode yang dibandingkan adalah metode AHP dan WP dalam pemilihan Biro perjalanan Umroh di Yogyakarta, metode AHP menghasilkan jumlah perubahan rangking sebesar 881 dan jumlah presentase sensitivitas sebesar $17.898 \%$, sedangkan metode WP menghasilkan jumlah perubahan rangking sebesar 
836 dan jumlah presentase sensitivitas sebesa 16.901\%. dapat disimpulkan bahwa metode AHP merupakan metode yang relavan dalam pemilihan biro perjalanan umroh [2].

Dari Hasil yang telah didapatkan dengan perhitungan metode AHP dan Metode SAW, diketahui bahwa menggunakan metode AHP lebih tepat untuk studi kasus pemilihan paket layanan internet dengan presentase perhitungan sebesar $84,62 \%$, sedangkan metode SAW memperoleh presentase sebesar $76,92 \%$ [3].

Diharapkan dengan menggunakan Metode AHP dapat membantu menyelesaikan permasalahan dalam menentukan BSM yang tepat sasaran.

\subsection{Penelitian Terkait}

\section{TINJAUAN PUSTAKA}

Dalam jurnal yang teliti oleh sefudin dan sri wahyuningsih (2014) dengan Judul Sistem Pendukung Keputusan Untuk Penilaian Kinerja Pegawai Menggunakan Metode Analytical Hierarchy Process (AHP) Pada RSUD Serang dengan masalah penilaian pegawai menggunakan kriteria Prestasi kerja, Tanggung jawab, Kejujuran, Kerjasama, Prakarsa, Ketaatan, Kepemimpinan dan Kesetiaan menggunakan metode AHP didapatkan hasil Hasil penelitian menunjukan bahwa bahwa sistem yang dibangung mampu memberikan hasil perhitungan secara otomatis sesuai dengan hasil perhitungan yang dilakukan secara manual [4].

Dalam jrunal yang diteliti oleh Akmaludin (2012) dengan Judul Evaluasi Analisis Efektifitas Copy Naskah Dengan Menggunakan Analytical Hierarchical Process dengan masalah tingkat efektivitas Copy Naskah menggunakan kriteria Data Processing, Formulasi, Design Output, transfer knowledge menggunakan metode AHP didapatkan hasil prioritas tahapan AHP pada tahap synthesize akan didapatkan oleh perolehen yang sama, bahwa DRM yang menjadi prioritas tertinggi dan menjadi keputusan bulan dalam pengambilan keputusan [5].

Dalam jurnal Internasional yang diteliti oleh Rahwati dan Dewi Ayu Nur Wulandari (2020) dengan Judul Sistem Pendukung Keputusan Kinerja Guru menggunakan Metode AHP dengan permasalahan Penilaian Guru menggunakan kriteria Tangung jawab, Disiplin, Kehadiran, kerja tim dan kualitas pekerjaan ditarik kesimpulan bahwa Metode AHP dapat digunkan untuk membnatu dalam pengambilan keputusan, ini karena metode AHP adalah model untuk pengambilan keputusan yang terstruktur dan komprehensif [6].

Dalam jurnal internasional yang diteliti oleh Dudih Gustian et.al (2017) yang berjudul Comparison of C4.5method based optimization algorithm to determine eligibility of beneficiaries of direct community assistance (Case study : Kelurahan Cicurug) dengan permasalah tidak tepat sasarannya Bantuan Langsung Masyarakat metode yang digunakan adalah C4.5 . metode penambangan data dipilih karena dapat menghasilkan model dan kriteria yang mudah diinterprestasikan oleh klasifikasi pelatihan data dan pengujian data algoritma Genetik (GA) sehingga dapat menjadi bentuk metode yang lebih baik [7].

\subsection{Metode Penelitian}

\section{METODE PENELITIAN}

1. Metode pengumpulan data Pengumpulan data dilakukan untuk memperoleh informasi yang dibutuhkan dalam rangka mencapai tujuan ada penelitian ini. Pengumpulan data pada penelitian ini sebagai berikut : 
a. Wawancara Wawancara dilakukan terhadap pihak-pihak terkait dalam Penerimaan Bantuan Siswa Miskin (BSM). Wawancara ini dilakukan kepada pihak SMK Bina Mandiri 2 yang berkaitan dengan penerimaan BSM untuk mengetahui cara dan faktor yang dipertimbangkan dalam penentuan penerima BSM di Sekolah tersebut.

b. Observasi Observasi dilakukan oleh peneliti bertujuan untuk mempelajari kondisi lingkungan objek penelitian yaitu SMK Bina Mandiri 2 . observasi pada penelitian ini mengukur sikap dari responden dan merekam berbagai kegiatan dan prilaku yang terjadi.

c. Kuesioner Kuesioner dalam penelitian ini bertujuan untuk mengumpulkan informasi yang memungkinkan penulis mempelajari prilaku dan karakteristik beberapa orang utama di penelitian yang bisa terpengaruh oeh sistem yang dirancang.

d. Study dan literatur Studi litelatur yang dilakukan oleh penulis yaitu dengan melakukan pencarian terhadap berbagai sumber tertulis baik berupa buku-buku, majalah artiker, jurnal atau dokumen dokumen yang relavan dengan permasalahan yang dikaji. Sehingga informasi yang didapat dari studi kepustakaan ini dijadikan rujukan untuk memperkuat argumentasi-argumentasi yang ada.

2. Analisis Data dengan AHP

Kemampuan metode AHP yang digunakan di sini adalah dalam analisis konsistensi dan analisis sensitivitas. Analisis konsistensi ditujukan terhadap hirarki prioritas yang dibangun. Sedangkan analisis sensitivitas dimaksudkan untuk meihat pengaruh setiap elemen terhadap hirarki rpioritas yang dibangun.

\subsection{Dengan metode Analytical Hierrachy Process}

AHP mempunyai kemampuan untuk memecahkan masalah yang multiobjektif dan multi-kriteria yang didasarkan pada perbandingan preferensi dari setiap elemen dalam hierarki. Jadi model ini merupakan suatu model pengambilan keputusan yang komprehensif. Prinsip-prinsip AHP sebagai berikut

a. Identifikasi Faktor Penyebab Berdasarkan Wawancara dan Observasi yang dilakukan maka didapatkan suatu penerima BSM terdapat beberapa factor diantarnya, status, Pengeluaran Orangtua, Prilaku, Penerima Kartu Miskin, Tempat Tinggal.

b. Penyusunan Hierarki Hirarki adalah abstraksi struktur suatu sistem yang mempelajari fungsi interaksi antara komponen dan juga dampak-dampaknya pada sistem. Penyusunan hirarki atau struktur keputusan dilakukan untuk menggambarkan elemen sistem atau alternatif keputusan yang teridentifikasi, misalnya saat metode Analytical Hierarchy Process yang menghasilkan suatu keputusan yang lebih objektif dengan pemberian nilai pada setiap kriteria kriteria yang telah ditentukan [8].

c. Penentuan Prioritas Untuk setiap kriteria dan alternatif, kita harus melakukan perbandingan berpasangan (pairwaise comparison) yaitu membandingkan setiap elemen dengan elemen lainnya pada setiap tingkat hirarki secara berpasangan sehingga didapat nilai tingkat kepentingan elemen dalam bentuk pendapat kualitatif. Untuk mengkuantifikasikan pendapat kualitatif tersebut digunakan skala penilaian sehingga akan diperoleh nilai pendapat dalam bentuk angka (kuantitatif). 


\subsection{Perancangan Sistem}

1. Use Case Diagram

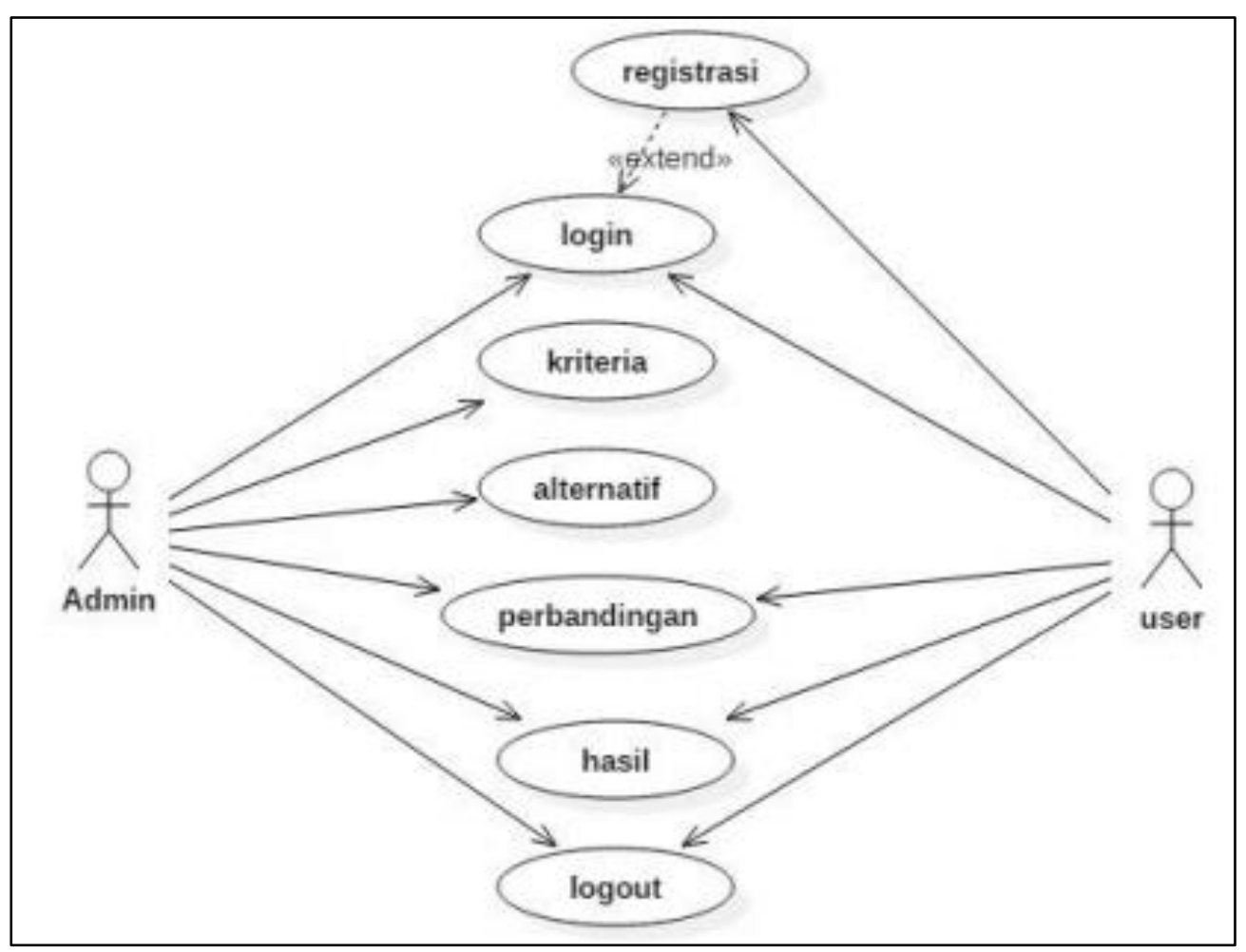

Gambar 2. Use Case Diagram

3. Class Diagram

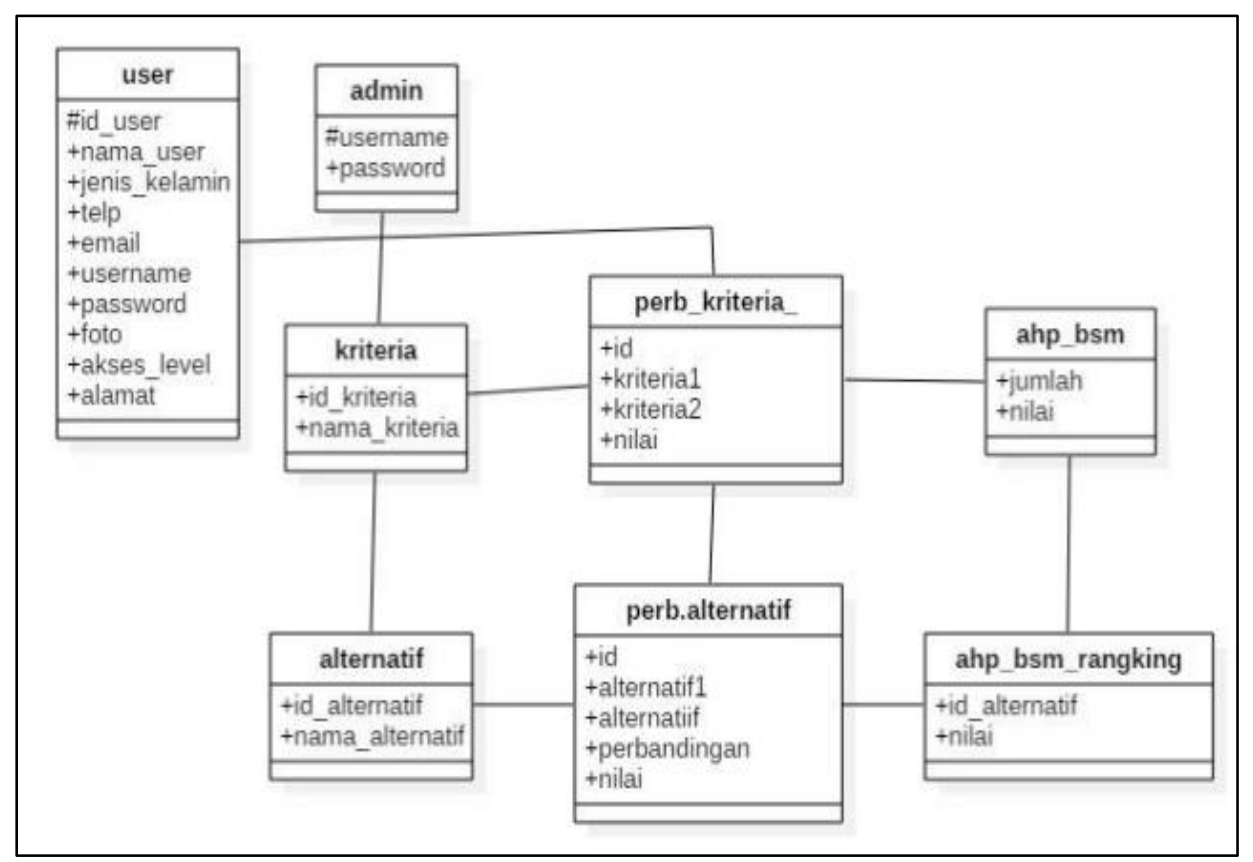

Gambar 3. Use Case Diagram 


\section{HASIL DAN PEMBAHASAN}

\subsection{Proses dengan AHP}

\section{Decomposiont}

Pada tahap ini adalah memecahkan atau membagi problem yang utuh menjadi unsur - unsur ke bentuk hirarki proses pengambilan keputusan, dimana setiap unsur atau elemen saling berhubungan. Bentuk struktur decomosiont yakni

Tingkat Pertama : : Tujuan Keputusan (Goal)

Tingkat Kedua $\quad$ : Kriteria - kriteria

Tingkat Ketiga : Alternatif - alternatif

Bentuk hirarki proses pada penentuan penerima BSM dapat dilihat pada gambar 4.

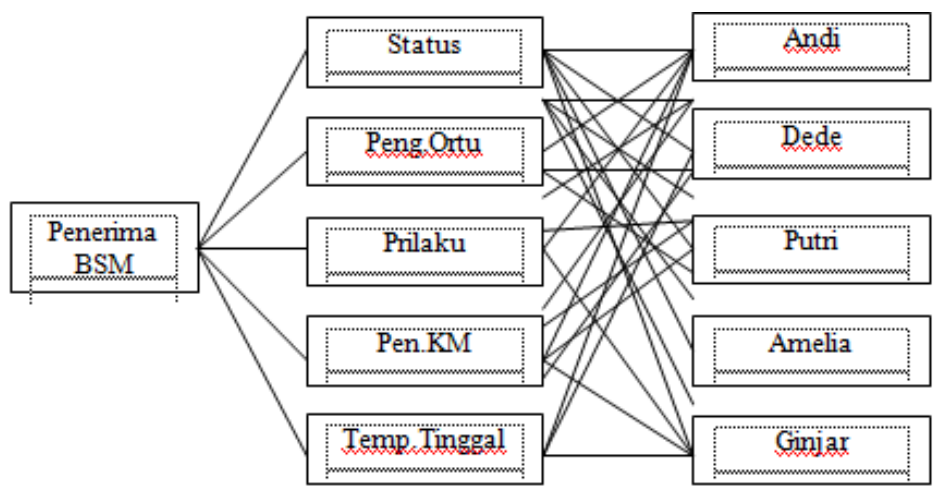

Gambar 4. Hirarki Pemilihan Penerima BSM

\section{Comparative Judgement}

Pada tahap ini dilakukan penilaian yang dilakukan berdasarkan kepentingan relatife dua elemen pada suatu tingkat tertentu dalam kaitannya dengan tingkatan di atasnya. Hasil dari penilaian tersebut akan diperlihatkan dalam bentuk matriks perbandingan berpasangan memuat tingkat preferensi beberapa alternative untuk tiap kriteria. Skala preferensi yang digunakan yaitu skala 1 yang menunjukan tingkat yang paling rendah sampai skala 9 yang menunjukan tingkatan paling tinggi. Matrik perbandingan dapat dilihat pada table 1 .

Tabel 1. Matrik Perbandingan Berpasangan

\begin{tabular}{|l|l|l|l|l|l|}
\hline Kriteria & Status & $\begin{array}{l}\text { Peng. } \\
\text { Ortu }\end{array}$ & Prilaku & $\begin{array}{l}\text { Pen. } \\
\text { KM }\end{array}$ & $\begin{array}{l}\text { Tempat } \\
\text { Tinggal }\end{array}$ \\
\hline Status & 1.00 & 0.33 & 0.5 & 3.00 & 3.00 \\
\hline Peng. Ortu & 3.00 & 1.00 & 3.00 & 3.00 & 3.00 \\
\hline Prilaku & 2.00 & 0.33 & 1.00 & 3.00 & 3.00 \\
\hline Pen. KM & 0.33 & 0.33 & 0.33 & 1.00 & 0.33 \\
\hline Tempat Tinggal & 0.33 & 0.33 & 0.33 & 3.00 & 1.00 \\
\hline Jumlah Total & 6.667 & 2.333 & 5.167 & 13.000 & 10.333 \\
\hline
\end{tabular}


Tabel 2. Matrik Normalisasi Perbandingan

\begin{tabular}{|l|l|l|l|l|l|l|}
\hline & Status & $\begin{array}{l}\text { Peng. } \\
\text { Ortu }\end{array}$ & Prilaku & $\begin{array}{l}\text { Pen } \\
\text { KM }\end{array}$ & $\begin{array}{l}\text { Tempat } \\
\text { Tinggal }\end{array}$ & $\begin{array}{l}\text { Vektor } \\
\text { Eigen }\end{array}$ \\
\hline Status & 0.150 & 0.143 & 0.097 & 0.231 & 0.290 & 0.182 \\
\hline Peng. Ortu & 0.450 & 0.429 & 0.581 & 0.231 & 0.290 & 0.396 \\
\hline Prilaku & 0.300 & 0.143 & 0.194 & 0.231 & 0.029 & 0.231 \\
\hline Pen KM & 0.050 & 0.143 & 0.065 & 0.077 & 0.032 & 0.073 \\
\hline Tem. Tinggal & 0.050 & 0.143 & 0.065 & 0.231 & 0.097 & 0.117 \\
\hline Jumlah Total & 1.00 & 1.00 & 1.00 & 1.00 & 1.00 & 1.00 \\
\hline
\end{tabular}

Setelah mencari Eigen tiap kolom dicari nilai Eigen max, lalu dilanjutkan dengan dengan mendapatkan nilai Eigen Maks selanjutnya menghitung nilai Consistency Index (CI) dengan Rumus :Hitung nilai Consistency Ratio (CR) Berdasarkan nilai Random Indek (RI) sebagai berikut :

Nilai $C R 0.001108$ menyatakan rasio konsistensi, karena nilai $C R$ lebih kecil dari nilai 0.1 .

\section{Penetuan Penerima BSM}

Penentu Penerima BSM dengan mencari nilai Matrik Perbandingan setiap kriteria dengan mengambil data siswa yang akan menerima BSM. Setelah menentukan dan menghitung matrik perbandingan setiap kriteria selanjutnya matriks erbandingan di normalisasi dan dicari nilai bobot alternatif, dapat dilihat pada tabel 3 dan tabel 4 .

Tabel 3. Matrik Perbandingan Status

\begin{tabular}{|l|l|l|l|l|l|l|}
\hline & & 20 & 60 & 20 & 20 & 40 \\
\hline & & Andi & Dede & Putri & Amelia & Ginjar \\
\hline 20 & Andi & 1.0000 & 0.3333 & 1.0000 & 1.0000 & 0.5000 \\
\hline 60 & Dede & 3.0000 & 1.0000 & 3.0000 & 3.0000 & 1.5000 \\
\hline 20 & Putri & 0.3333 & 0.3333 & 1.0000 & 1.0000 & 0.5000 \\
\hline 20 & Amelia & 1.0000 & 0.3333 & 1.0000 & 1.0000 & 0.5000 \\
\hline 40 & Ginjar & 2.0000 & 0.6667 & 2.0000 & 1.0000 & 1.0000 \\
\hline & Total & 7.3333 & 2.6667 & 8.0000 & 7.0000 & 4.0000 \\
\hline
\end{tabular}

Tabel 4. Mencari nilai bobot alternatife Status

\begin{tabular}{|l|l|l|l|l|l|l|}
\hline Status & Andi & Dede & Putri & Amelia & Ginjar & $\begin{array}{l}\text { Nilai } \\
\text { Eigen }\end{array}$ \\
\hline Andi & 0.1364 & 0.1250 & 0.1250 & 0.1429 & 0.1250 & 0.1308 \\
\hline Dede & 0.4091 & 0.3750 & 0.3750 & 0.4286 & 0.3750 & 0.3925 \\
\hline Putri & 0.0455 & 0.1250 & 0.1250 & 0.1429 & 0.1250 & $0 . .1127$ \\
\hline Amelia & 0.1364 & 0.1250 & 0.1250 & 0.1429 & 0.1250 & 0.1308 \\
\hline Ginjar & 0.2727 & 0.2500 & 0.2500 & 0.1429 & 0.1250 & 0.2331 \\
\hline Total & 1.0000 & 1.0000 & 1.0000 & 1.0000 & 1.0000 & 1.0000 \\
\hline
\end{tabular}


Tabel 5. Matrik Perbandingan Penghasilan Orang Tua

\begin{tabular}{|l|l|l|l|l|l|l|}
\hline \multicolumn{2}{|c}{} & 80 & 80 & 49 & 60 & 10 \\
\cline { 3 - 7 } & & & & & & \\
\hline 80 & Andi & Dede & Putri & Amelia & Ginjar \\
\hline 80 & Dede & 1.0000 & 1.0000 & 2.0000 & 1.3333 & 8.0000 \\
\hline 40 & Putri & 0.5000 & 0.5000 & 1.0000 & 1.3333 & 4.0000 \\
\hline 60 & Amelia & 0.7500 & 0.7500 & 1.5000 & 1.0000 & 6.0000 \\
\hline 10 & Ginjar & 0.1250 & 0.1250 & 0.2500 & 0.1667 & 1.0000 \\
\hline & Total & 3.3750 & 3.3750 & 6.7500 & 4.5000 & 27.000 \\
\hline
\end{tabular}

Tabel 6. Mencari Nilai Bobot Alternatif Penghasilan Orangtua

\begin{tabular}{|l|l|l|l|l|l|l|l|}
\hline \multicolumn{2}{|c|}{} & 80 & 80 & 49 & 60 & 10 & \\
\cline { 2 - 8 } & Andi & Dede & Putri & Amelia & Ginjar & $\begin{array}{l}\text { Nilai } \\
\text { Eigen }\end{array}$ \\
\hline 80 & Andi & 0.2963 & 0.2963 & 0.2963 & 0.2963 & 0.2963 & 0.2963 \\
\hline 80 & Dede & 0.2963 & 0.2963 & 0.2963 & 0.2963 & 0.2963 & 0.2963 \\
\hline 40 & Putri & 0.1481 & 0.1481 & 0.1481 & 0.1481 & 0.1481 & 0.1481 \\
\hline 60 & Amelia & 0.2222 & 0.2222 & 0.2222 & 0.2222 & 0.2222 & 0.2222 \\
\hline 10 & Ginjar & 1.0000 & 0.0370 & 0.0370 & 0.0370 & 0.0370 & 0.0370 \\
\hline & Total & 1.0000 & 1.0000 & 1.0000 & 1.0000 & 1.0000 & 1.0000 \\
\hline
\end{tabular}

Tabel 7. Matrik Perbandingan Prilaku

\begin{tabular}{|l|l|l|l|l|l|l|}
\hline \multicolumn{2}{|c|}{} & 80 & 80 & 85 & 70 & 80 \\
\cline { 3 - 7 } \multicolumn{2}{|c|}{} & Andi & Dede & Putri & Amelia & Ginjar \\
\hline 75 & Andi & 1.0000 & 0.8824 & 1.0714 & 10000 & 0.9375 \\
\hline 85 & Dede & 1.1333 & 1.0000 & 1.2143 & 1.1333 & 1.0625 \\
\hline 85 & Putri & 0.9333 & 0.8235 & 1.0000 & 0.9333 & 0.8750 \\
\hline 75 & Amelia & 1.0000 & 0.8824 & 1.0714 & 1.0000 & 0.9375 \\
\hline 80 & Ginjar & 1.0667 & 0.9412 & 1.1429 & 1.0667 & 1.0000 \\
\hline & Total & 5.1333 & 4.5294 & 5.5000 & 5.1333 & 4.8125 \\
\hline
\end{tabular}

Tabel 8. Mencari Nilai Bobot Alternatif Prilaku

\begin{tabular}{|l|l|l|l|l|l|l|l|}
\hline \multicolumn{2}{|l|}{} & Andi & Dede & Putri & Amelia & Ginjar & Nilai Eigen \\
\hline 75 & Andi & 0.1948 & 0.1948 & 0.1948 & 0.1948 & 0.1948 & 0.1948 \\
\hline 85 & Dede & 0.2208 & 0.2208 & 0.2208 & 0.2208 & 0.2208 & 0.2208 \\
\hline 85 & Putri & 0.1818 & 0.1818 & 0.1818 & 0.1818 & 0.1818 & 0.1818 \\
\hline 75 & Amelia & 0.1948 & 0.1948 & 0.1948 & 0.1948 & 0.1948 & 0.1948 \\
\hline 80 & Ginjar & 0.2078 & 0.2078 & 0.2078 & 0.2078 & 0.2078 & 0.2078 \\
\hline & Total & 1.0000 & 1.0000 & 1.0000 & 1.0000 & 1.0000 & 1.0000 \\
\hline
\end{tabular}


Tabel 9. Matrik Perbandingan Penerimaan Kartu Miskin

\begin{tabular}{|l|l|l|l|l|l|l|}
\hline \multicolumn{2}{|c|}{} & 40 & 60 & 20 & 40 & 20 \\
\cline { 3 - 7 } & & Andi & Dede & Putri & Amelia & Ginjar \\
\hline 40 & Andi & 10000 & 0.6667 & 2.0000 & 1.0000 & 2.0000 \\
\hline 60 & Dede & 15000 & 10000 & 3.0000 & 1.5000 & 3.0000 \\
\hline 20 & Putri & 0.5000 & 0.3333 & 1.0000 & 0.5000 & 1.0000 \\
\hline 40 & Amelia & 10000 & 0.6667 & 20000 & 10000 & 20000 \\
\hline 20 & Ginjar & 0.5000 & 0.3333 & 10000 & 0.5000 & 10000 \\
\hline & Total & 4.5000 & 30000 & 90000 & 4.5000 & 9.0000 \\
\hline
\end{tabular}

Tabel 10. Mencari Nilai Bobot Alternatif Penerima Kartu Miskin

\begin{tabular}{|l|l|l|l|l|l|l|l|}
\hline \multicolumn{2}{|l|}{} & Andi & Dede & Putri & Amelia & Ginjar & $\begin{array}{l}\text { Nilai } \\
\text { Eigen }\end{array}$ \\
\hline 40 & Andi & 0.2222 & 0.2222 & 0.2222 & 0.2222 & 0.2222 & 0.2222 \\
\hline 60 & Dede & 0.3333 & 0.3333 & 0.3333 & 0.3333 & 0.3333 & 0.3333 \\
\hline 20 & Putri & 0.1111 & 0.1111 & 0.1111 & 0.1111 & 0.1111 & 0.1111 \\
\hline 40 & Amelia & 0.2222 & 0.2222 & 0.2222 & 0.2222 & 0.2222 & 0.2222 \\
\hline 20 & Ginjar & 0.1111 & 0.1111 & 0.1111 & 0.1111 & 1.0000 & 0.1111 \\
\hline & Total & 1.0000 & 1.0000 & 1.0000 & 1.0000 & 1.0000 & 1.0000 \\
\hline
\end{tabular}

Tabel 11. Matrik Perbandingan Tempat Tinggal

\begin{tabular}{|l|l|l|l|l|l|l|}
\hline \multicolumn{2}{|c|}{} & 40 & 30 & 20 & 30 & 40 \\
\cline { 3 - 7 } & & Andi & Dede & Putri & Amelia & Ginjar \\
\hline 40 & Andi & 1.0000 & 1.0000 & 0.7500 & 0.7500 & 0.5000 \\
\hline 30 & Dede & 1.0000 & 1.0000 & 0.7500 & 0.7500 & 0.5000 \\
\hline 20 & Putri & 1.3333 & 1.3333 & 1.0000 & 1.0000 & 0.6667 \\
\hline 30 & Amelia & 1.3333 & 1.3333 & 1.0000 & 1.0000 & 0.6667 \\
\hline 40 & Ginjar & 2.0000 & 2.0000 & 1.5000 & 1.5000 & $1.000 \mathrm{o}$ \\
\hline & Total & 6.6667 & 6.6667 & 5.0000 & 5.0000 & 3.3333 \\
\hline
\end{tabular}

Tabel 12. Mencari Nilai Bobot Alternatif Tempat Tinggal

\begin{tabular}{|l|l|l|l|l|l|l|}
\hline & Andi & Dede & Putri & Amelia & Ginjar & $\begin{array}{l}\text { Nilai } \\
\text { Eigen }\end{array}$ \\
\hline Andi & 0.1500 & 0.1500 & 0.1500 & 0.1500 & 0.1500 & 0.1500 \\
\hline Dede & 0.1500 & 0.1500 & 0.1500 & 0.1500 & 0.1500 & 0.1500 \\
\hline Putri & 0.2000 & 0.2000 & 0.2000 & 0.2000 & 0.2000 & 0.2000 \\
\hline Amelia & 0.2000 & 0.2000 & 0.2000 & 0.2000 & 0.2000 & 0.2000 \\
\hline Ginjar & 0.3000 & 0.3000 & 0.3000 & 0.3000 & 0.3000 & 0.3000 \\
\hline Total & 1.0000 & 1.0000 & 1.0000 & 1.0000 & 1.0000 & 1.0000 \\
\hline
\end{tabular}

Selanjutnya encari nilai matrik dengan menjumlahkan Bobot Alternatif dengan bobot prioritas. 
Tabel 13. Nilai Bobot

\begin{tabular}{|l|l|l|l|l|l|l|}
\hline & Status & $\begin{array}{l}\text { Peng. } \\
\text { Ortu }\end{array}$ & Prilaku & $\begin{array}{l}\text { Pen. } \\
\text { KM }\end{array}$ & $\begin{array}{l}\text { Tempat } \\
\text { Tinggal }\end{array}$ & $\begin{array}{l}\text { Nilai } \\
\text { Bobot }\end{array}$ \\
\hline Andi & 13.000 & 0.3000 & 0.1900 & 0.2222 & 0.1500 & 0.2212 \\
\hline Dede & 0.3930 & 0.3000 & 0.2222 & $0 . .3300$ & 0.1500 & 0.0129 \\
\hline Putri & 0.1130 & 0.1500 & 0.18000 & 0.1100 & 0.2000 & 0.1531 \\
\hline Amelia & 0.1310 & 0.2200 & 0.1900 & 0.2200 & 0.2000 & 0.1945 \\
\hline Ginjar & 0.2330 & 0.0400 & 0.2100 & 0.1100 & 0.3000 & 0.1485 \\
\hline
\end{tabular}

Pada Tabel 13 dapat ditarik kesimpulan dengan melihat nilai matrik tertinggi, perangkingan.

Tabel 14. Peringkat Penerima BSM

\begin{tabular}{|l|l|l|}
\hline $\begin{array}{l}\text { Penerima } \\
\text { BSM }\end{array}$ & $\begin{array}{l}\text { Nilai } \\
\text { Matrik }\end{array}$ & Rangking \\
\hline Andi & 0.2212 & 1 \\
\hline Dede & 0.0129 & 5 \\
\hline Putri & 0.1531 & 3 \\
\hline Amelia & 0.1945 & 2 \\
\hline Ginjar & 0.1485 & 4 \\
\hline
\end{tabular}

Dari tabel diatas dapat ditarik kesimpulan bahwa Andi adalah siswa yang harus diutamakan dalam penerima BSM karena memiliki nilai matrik paling tinggi, dan penerima BSM tingkat ke dua adalah Amelia, ketiga Putri, keempat Ginjar dan kelima adalah Dede.

\section{Perancangan Sistem}

Perancangan Sistem Informasi Berbasis WEB dengan menggunakan PHP dan MySQL di program pendukung keputusan penerima bsm sebagai berikut :

1. Halaman Login

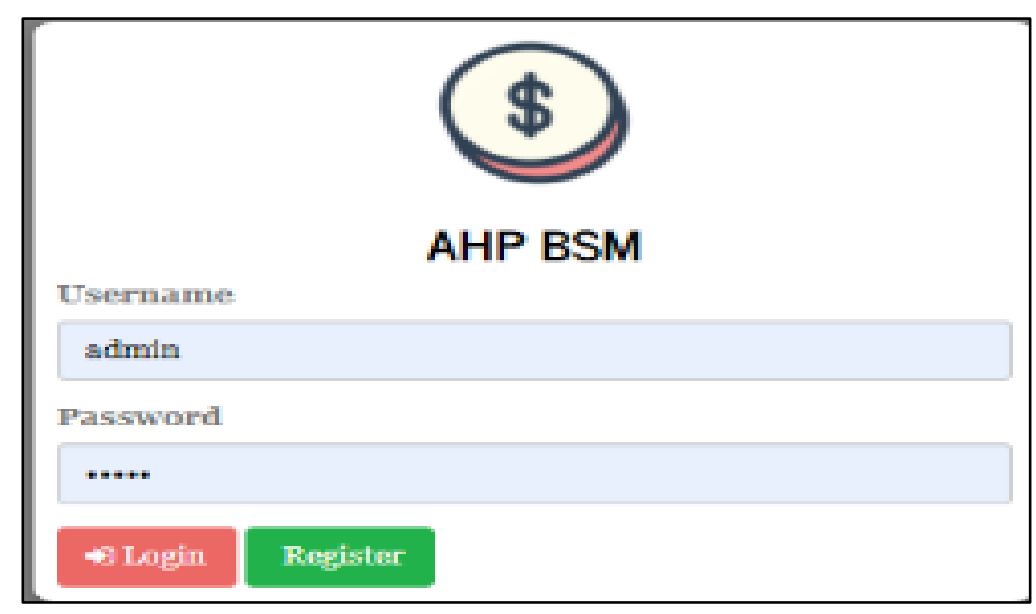

Gambar 5. Halaman Login 
2. Halaman Input Kriteria

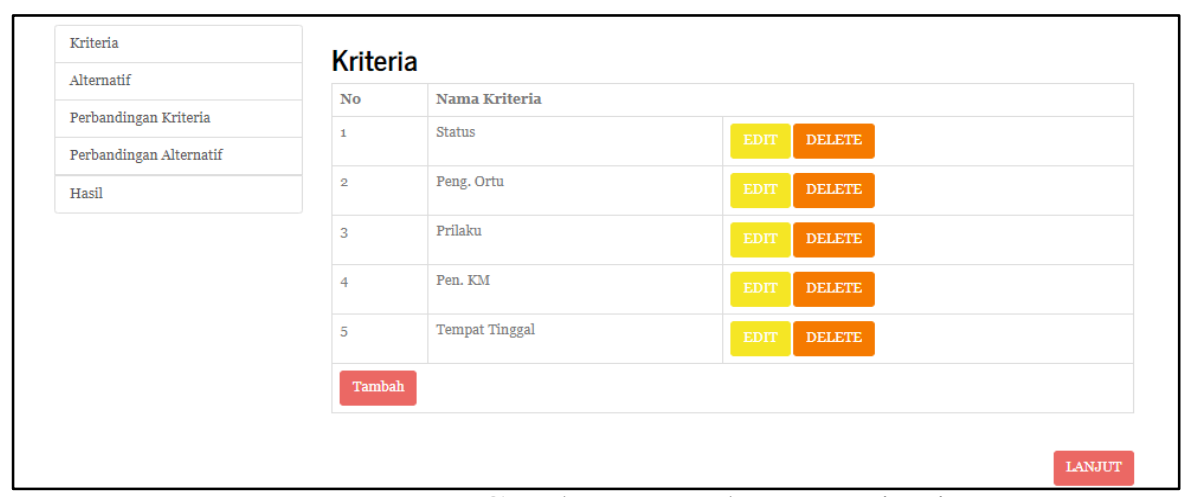

Gambar 6. Halaman Kriteria

3. Halaman Alternatif

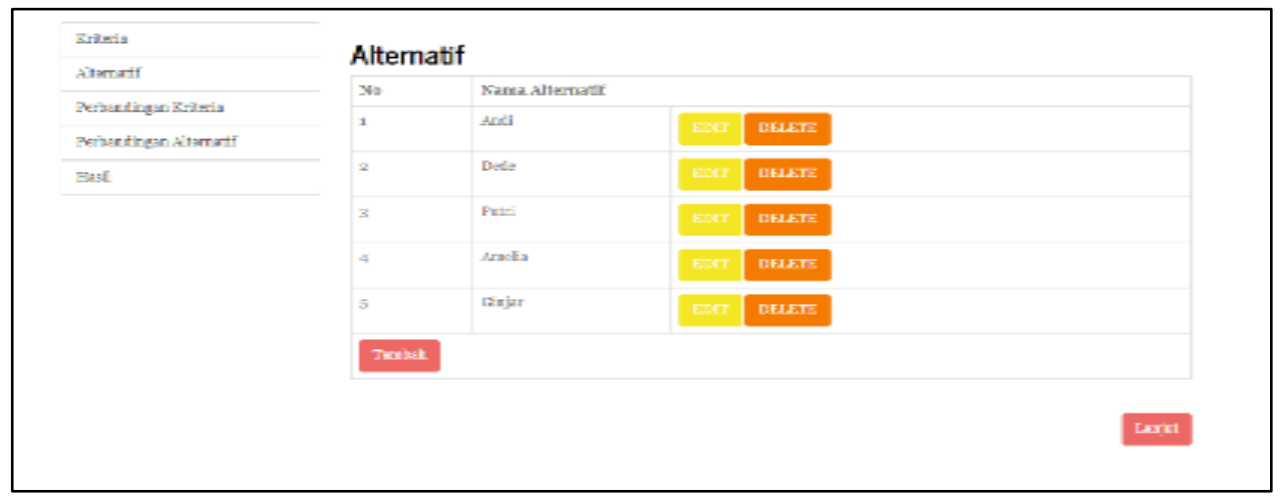

Gambar 7. Halaman Alternatif

4. Halaman Perbandingan Kriteria

\begin{tabular}{|c|c|c|c|}
\hline \multicolumn{2}{|c|}{ pilih yang lebih penting } & \multirow{2}{*}{$\begin{array}{l}\text { nilai perbandingan } \\
\text { 1. Sama pentingnya (Equal Importance) }\end{array}$} & \multirow[b]{2}{*}{$\sim$} \\
\hline Status & Peng. Ortu & & \\
\hline Status & Prilaku & 1. Sama pentingnya (Equal Importance) & $\sim$ \\
\hline Status & Pen. KM & 1. Sama pentingnya (Equal Importance) & $\sim$ \\
\hline Status & Tempat Tinggal & 1. Sama pentingnya (Equal Importance) & 2 \\
\hline Peng. Ortu & Prilaku & 1. Sama pentingnya (Equal Importance) & $\checkmark$ \\
\hline Peng. Ortu & Pen. KM & 1. Sama pentingnya (Equal Importance) & $\sim$ \\
\hline Peng. Ortu & Tempat Tinggal & 1. Sama pentingnya (Equal Importance) & $\sim$ \\
\hline Prilaku & Pen. KM & 1. Sama pentingnya (Equal Importance) & $\checkmark$ \\
\hline Prilaku & Tempat Tinggal & 1. Sama pentingnya (Equal Importance) & $\sim$ \\
\hline Pen. KM & Tempat Tinggal & 1. Sama pentingnya (Equal Importance) & $\sim$ \\
\hline
\end{tabular}




\section{Halaman Perhitungan}

\begin{tabular}{|c|c|c|c|c|c|c|c|c|c|c|}
\hline \multicolumn{11}{|c|}{ Matriks Perbandingan Berpasangan } \\
\hline \multicolumn{2}{|l|}{ Kriteria } & \multicolumn{2}{|c|}{ Status } & \multicolumn{2}{|c|}{ Peng. Ortu } & \multicolumn{2}{|c|}{ Prilaku } & Pen. KM & \multicolumn{2}{|c|}{ Tempat Tinggal } \\
\hline \multicolumn{2}{|l|}{ Status } & \multicolumn{2}{|c|}{1} & \multicolumn{2}{|l|}{2} & \multicolumn{2}{|l|}{1} & 5 & \multicolumn{2}{|l|}{1} \\
\hline \multicolumn{2}{|l|}{ Peng. Ortu } & \multicolumn{2}{|c|}{0.5} & \multicolumn{2}{|l|}{1} & \multicolumn{2}{|l|}{3} & 1 & \multicolumn{2}{|l|}{3} \\
\hline \multicolumn{2}{|l|}{ Prilaku } & \multicolumn{2}{|c|}{1} & \multicolumn{2}{|c|}{0.33333} & \multicolumn{2}{|l|}{1} & 1 & \multicolumn{2}{|l|}{3} \\
\hline \multicolumn{2}{|l|}{ Pen. KM } & \multicolumn{2}{|c|}{0.2} & \multicolumn{2}{|l|}{1} & \multicolumn{2}{|l|}{1} & 1 & \multicolumn{2}{|l|}{1} \\
\hline \multicolumn{2}{|l|}{ Tempat Tinggal } & \multicolumn{2}{|c|}{1} & \multicolumn{2}{|c|}{0.33333} & \multicolumn{2}{|c|}{0.33333} & 1 & \multicolumn{2}{|l|}{1} \\
\hline \multicolumn{2}{|l|}{ Jumlah } & \multicolumn{2}{|l|}{3.7} & \multicolumn{2}{|c|}{4.66667} & \multicolumn{2}{|c|}{6.33333} & 9 & 9 & \\
\hline Matriks Nila & Kriter & & & & & & & & & \\
\hline Kriteria & Status & & Peng. 0 & rtu & Prilaku & Pen. KM & Ter & pat Tinggal & Jumlah & Priority Vector \\
\hline Status & 0.2702 & & 0.42857 & & 0.15789 & 0.55556 & 0.11 & & 1.5234 & 0.30468 \\
\hline Peng. Ortu & 0.13514 & & 0.21429 & & 0.47368 & 0.11111 & 0.3 & & 1.26755 & 0.25351 \\
\hline Prilaku & 0.2702 & & 0.07143 & & 0.15789 & 0.11111 & 0.3 & & 0.94404 & 0.18881 \\
\hline Pen. KM & 0.0540 & & 0.21429 & & 0.15789 & 0.11111 & 0.11 & & 0.64846 & 0.12969 \\
\hline Tempat Tinggal & 0.2702 & & 0.07143 & & 0.05263 & 0.11111 & 0.1 & & 0.61655 & 0.12331 \\
\hline Principe Eiger & Vector ( & $(\lambda \mathrm{ma}$ & laks) & & & & & & & $5.78_{316}$ \\
\hline Consistency Ir & & & & & & & & & & 0.19579 \\
\hline
\end{tabular}

Gambar 9. Halaman Perhitungan

6. Halaman Hasil

\begin{tabular}{|c|c|c|c|c|c|c|c|}
\hline \multicolumn{8}{|l|}{ Hasil Perhitungan } \\
\hline Overall Composite Height & \multicolumn{2}{|c|}{ Priority Vector (rata-rata) } & Andi & Dede & Putri & Amelia & Ginjar \\
\hline Status & \multicolumn{2}{|l|}{0.30468} & 0.26023 & 0.24919 & 0.16593 & 0.19246 & 0.1322 \\
\hline Peng. Ortu & \multicolumn{2}{|l|}{0.25351} & 0.2 & 0.2 & 0.2 & 0.2 & 0.2 \\
\hline Prilaku & \multicolumn{2}{|l|}{0.18881} & 0.21845 & 0.26401 & 0.2403 & 0.12324 & 0.15401 \\
\hline Pen. KM & \multicolumn{2}{|l|}{0.12969} & 0.25698 & 0.21897 & 0.23032 & 0.15865 & 0.13508 \\
\hline Tempat Tinggal & \multicolumn{2}{|l|}{0.12331} & 0.42633 & 0.24174 & 0.15126 & 0.09328 & 0.0874 \\
\hline \multicolumn{3}{|l|}{ Total } & 0.25713 & 0.23468 & 0.19515 & 0.16469 & 0.14835 \\
\hline \multicolumn{8}{|l|}{ Perangkingan } \\
\hline \multicolumn{2}{|l|}{ Peringkat } & \multicolumn{3}{|l|}{ Alternatif } & \multicolumn{3}{|l|}{ Nilai } \\
\hline \multicolumn{2}{|l|}{ Pertama } & \multicolumn{3}{|l|}{ Andi } & \multicolumn{3}{|l|}{0.257133} \\
\hline \multicolumn{2}{|l|}{2} & \multicolumn{3}{|l|}{ Dede } & \multicolumn{3}{|l|}{0.23468} \\
\hline \multicolumn{2}{|l|}{3} & \multicolumn{3}{|l|}{ Putri } & \multicolumn{3}{|l|}{0.195149} \\
\hline \multicolumn{2}{|l|}{4} & \multicolumn{3}{|l|}{ Amelia } & \multicolumn{3}{|l|}{0.164685} \\
\hline \multicolumn{2}{|l|}{5} & \multicolumn{3}{|l|}{ Ginjar } & \multicolumn{3}{|l|}{0.148353} \\
\hline
\end{tabular}

Gambar 10. Halaman Hasil 


\section{KESIMPULAN}

Dengan menerapkan metode Analitycal Hierarchy procces pada proses penerimaan BSM bagi siswa lebih efesien sehingga pihak smk Bina Mandii 2 lebih cepat dalam proses pengambilan keputusan yang bersifat objektif. Setelah dilakukan penilaian pada aplikasi SPK penerimaan BSM dengan 5 siswa yaitu Andi, Dede, Putri, Amelia dan Ginjar didapat hasil nilai akhir dengan skor tertinggi 0.2212 yaitu Andi. Sistem penunjang keputusan untuk penentuan penerima BSM menggunakan metode AHP yang dibuat dengan menggunakan bahasa pemrograman Php dan SQLyog sebagai database.

\section{DAFTAR PUSTAKA}

[1] Syafnidawaty. Kelebihan dan kekurangan Metode AHP (Analytic Hierarchy Process). Universitas rahara, 2020.

[2] Syaka, Annisa khodista, \& Agus Mulyanto. Analisis Perbandingan Sensitivitas AHP dan WP dalam pemilihan Biro Perjalanan Umrah di Yogyakarta. Universitas Islam Negeri Sunan Kalijaga : Yogyakarta, 2019.

[3] D. Pawestri, et.al. Perbandingan Penggunaan Metode AHP dan SAW untuk Sistem Pendukung Keputusan Pemilihan Paket Layanan Internet. Universitas Sebelas Maret : Jurnal Itsmart. 2019.

[4] Saefudin, \& S.Wahyuningsih. Sistem Pendukung Keputusan untuk penilaian Kinerja Pegawai Menggunakan Metode Analytical Hierarchy Process (AHP) pada RSUD Serang. Universitas Serang Raya : Jurnal Sistem Informasi Vol-1 No.1. 2014.

[5] Akmaludin. Evaaluasi Analisis Efektifitas Copy Naskah Dengan Menggunakan Analytical Hierarchical Process. Pilar Nusa Mandiri : Jakarta Pusat. 2012.

[6] Rahmawati, \& D. Ayu. Sistem Pendukung Keputusan Kinerja Guru Menggunakan AHP. Jurnal PILAR Nusa Mandiri : P-ISSN : 1978-1946, E-ISSN : 2527-6514. 2020.

[7] D. Gustian, et.al. Comparison of C4.5method based optimization algorithm to determine eligibility of beneficiaries of direct community assistance (Case study : Kelurahan Cicurug. International Conference on Computing, Engineering, and Design (ICCED). 2017.

[8] D. Gustian, et.al. Sistem Keputusan Penilaian Kinerja Karyawan dengan Menggunakan Metode Analiticalhierracy PROCESS, Jurnal TAM (Technology Acceptance Model) Volume 9, Nomor 2, Desember 2018. 